\title{
Shadows, Illusions, and Realities in the History of Modern Manchuria
}

A review of Manchuria under Japanese Domination by Yamamuro Shin'ichi, translated by Joshua A. Fogel, University of Pennsylvania Press, 2006

\section{Christopher Howe}

\section{(2) OpenEdition \\ 12 Journals}

\section{Édition électronique}

URL : http://journals.openedition.org/chinaperspectives/2533

DOI : $10.4000 /$ chinaperspectives. 2533

ISSN : 1996-4617

Éditeur

Centre d'étude français sur la Chine contemporaine

\section{Édition imprimée}

Date de publication : 15 décembre 2007

ISSN : 2070-3449

Référence électronique

Christopher Howe, "Shadows, Illusions, and Realities in the History of Modern Manchuria », China Perspectives [En ligne], 2007/4 | 2007, mis en ligne le 30 décembre 2010, consulté le 28 octobre 2019. URL : http://journals.openedition.org/chinaperspectives/2533; DOI : 10.4000/chinaperspectives.2533 
C

\title{
Shadows, Illusions, and
}

\section{Realities in the History}

of Modern Manchuria

\author{
A review of Manchuria under Japanese Dominion by Yamamuro Shin'ichi, \\ translated by Joshua A. Fogel, University of Pennsylvania Press, 2006
}

\section{CHRISTOPHER HOWE}

$\int \mathrm{n}$ n the second week of July 1971, Henry Kissinger visited Beijing in the greatest secrecy. So little did Kissinger and his group know of contemporary China that they assumed, quite wrongly, that the anti-American slogans glimpsed as they sped through Beijing had been put up for the express benefit of their visit. This visit, which presaged a tectonic shift in the politics of Asia and the Pacific, was revealed to the world on 15 July. The Japanese Ambassador in Washington was informed barely one hour before the public announcement, and Prime Minister Sato in Tokyo had only minutes of notice.

The following February Nixon signed the Shanghai Communiqué, and within three months Sato was gone and the campaign for presidency of the Liberal Democrat Party was underway. In this election the successful anti-Sato forces were committed to the immediate normalisation of relations with China.

In spite of a lack of formal ties, Japan's trade with China had actually grown with extraordinary speed in the years preceding this breakthrough - rising from 1.6 percent of China's global trade in 1960 to nearly 20 percent by 1970 . But this was largely trade with small "friendly firms" and "dummy" corporations. Most large corporations had stuck with the Sato line, through which they enjoyed the benefits of close relations with Taiwan that in many cases went back to the early part of the century. ${ }^{(1)}$

As normalisation approached in the summer of 1972, the appetite for knowledge about China in those Japanese business circles was enormous. As a visiting "China specialist" working in Japan that summer on the economic history of pre-war Manchuria, I was called upon to provide some talks. At the end of one of these sessions, a gentleman sitting immediately to my right leaned across and said: "You might be interested to know that I was a signatory to the surrender of the Kwantung Army in 1945." He added that if I wanted to understand the Manchurian political legacy I must study the writings of Ishiwara Kenji. Apart from the advice on Ishiwara, I took away from this and subsequent experiences two basic impressions: the first was that during

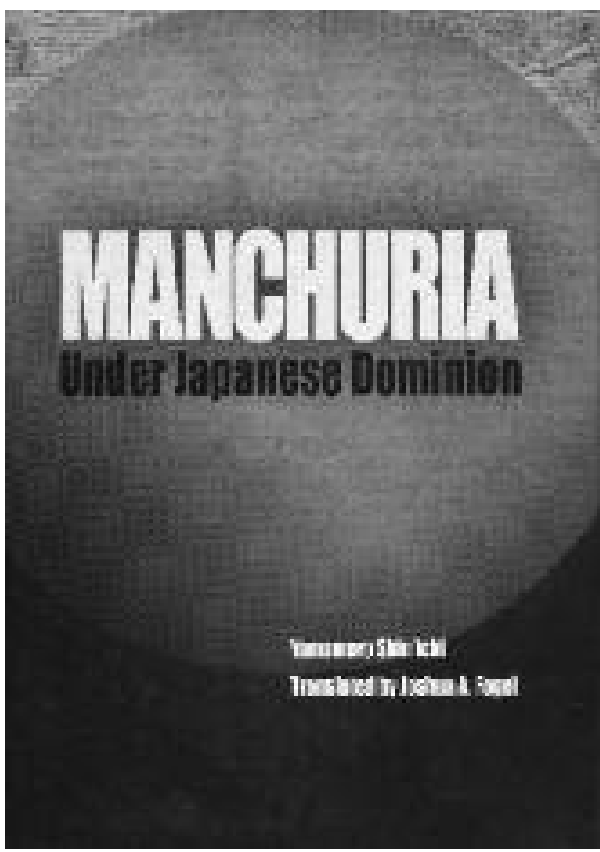
those years an extraordinarily high percentage of senior Japanese had background in Manchuria. In some cases their background was as officials, in others as businessmen, professional experts of all kinds, military personnel, or as relatives of those who had such connections. These Manchurian personal histories were not prominently discussed, certainly not with foreigners, but nonetheless, and notwithstanding the often tragic outcomes, Manchurian days had been for many the most idealistic, fulfilling, and extraordinary times of their lives.

1. Yoshihide Soeya, Japan's Economic Diplomacy with China, 1945-1978, Clarendon Press, Oxford, 1998, Chapter 6; Margaret Macmillan, When Nixon met Mao, London, John Murray, 2006 
My second impression was that Japanese businessmen considered Japan's occupation of Manchuria and China proper to have done immense economic damage (indeed, they found it difficult to credit Anglo-American estimates of China's economic performance in the 1950s and 1960s), ${ }^{(2)}$ and they therefore felt that Japan owed China a huge but unquantified economic debt. The Chinese leadership played cleverly on this, and it was undoubtedly a factor in the Japanese willingness to sign contracts during the "China boom" of 1972-1978. This early post-war flowering in SinoJapanese relations, therefore, reflected attitudes towards China based on firsthand experience, frequently in Manchuria. But as Shinichi Yamamuro points out in the major study reviewed here, "The number of people who have no knowledge of Manzhouguo increases with each passing day." For the younger generation, both in Japan and in a long-unified People's Republic of China, Manchuria is both an historical legacy and an experience easily transmuted into myths - myths that today still give rise to disturbing political emotions and have serious consequences for Sino-Japanese relations.

These are some of the broader issues explored in Shin ichi Yamamuro's Manchuria under Japanese Domination, translated from his Kimera: Manshukoku no Shozo (Chimera: A portrait of Manchuria). First published in 1993, his book now comes with additional material in the form of afterthoughts and an interview with the author.

Much work has been done by Japanese historians on the history of Manchuria, but Yamamuro's book represents an important individual attempt to probe the complicated political realities of the state of Manzhouguo (Manchukuo), which lasted from 1932 until 1945. ${ }^{(3)}$ The work is based on a huge variety of documentary and non-documentary resources, and benefits from being written at time when factual investigation is being enriched by a more discursive form of history. In making this work available in English, Joshua Fogel has done the international scholarly community a wonderful service. Translating reflective Japanese writing of this kind is exceedingly difficult, and it is not surprising that the task has taken Fogel so many years, but the end result has been brilliantly accomplished.

The over-arching idea of Yamamuro's work is summed up in his concept of the "chimera" - a mythical beast with the head of a lion and the tail of a serpent. Yamamuro uses this metaphor of illusion tainted with horror to describe the 13year history of Manzhouguo as a construct once driven by ideals and illusions that brought disaster to China and to Japan itself, but which is now fading into a dreamlike form in both countries.
This article discusses the background to the Manzhouguo experience, points out the major themes of Yamamuro's work, and relates it to the longer running story of western writing about Manchuria. This is a field that is still flourishing and developing as new historical sources are explored and as new experiences in the development of northeast Asia unfold and throw retrospective light on the underlying structural realities of the region.

\section{The background to Manzhouguo}

What, then, was the background of the Japanese military intervention in the "Mukden incident" of 1931 and the subsequent formation of the state of Manzhouguo in 1932?

Manchuria is very much a case that requires distinguishing structure and the longue durée from accidents and événements. ${ }^{(4)}$ In particular, it is important to understand what structures were critical to an understanding not only of Manchuria, but also of Mongolia; although politically distinct, as Yamamuro shows, Mongolia was so integral to Japanese thinking that the Manchurian question was frequently referred to as the Man-Mo (Manchuria-Mongolia) question.

Manchuria is defined physically by mountain ranges, its central plain, and vast river systems. These rivers mark natu$\mathrm{ral} /$ political boundaries and important transport arteries that run through the interior. To the north and east, the Amur and Ussuri perform both border and economic functions, while the Sungari, the Nonni, and the Liao rivers are crucial for internal transport.

Climatic factors are also important elements in Manchurian history. The long winters and short growing season determine the nature and labour requirements in the plain and in the valleys, where various forms of temperate agriculture are possible. In contrast to "traditional" China south of the Yangtze, this agriculture focuses mainly on forestry and the cultivation of pulses, maize, and traditional cold climate crops. Of great importance after the turn of the century was

2. It should be borne in mind that much published information in Japanese up to 1972 was produced by left-wing sympathisers in publications such as Jinmin Chûgoku (People's China) and Shin Chûgoku nenkan (New China Yearbook). These publications contained much useful information, but surrounded it in a rosy halo of Maoist ideology.

3. Manzhouguo is the standard Chinese romanisation of the name of the state commonly referred to as Manchukuo, which lasted from 1932 to 1945. Mansh koku is the Japanese form of this name, while "Manchuria" refers to the original three north-eastern provinces now commonly known in China as dongbei.

4. Michele Vovelle, "L'histoire et la longue durée," in Jacques Le Goff (ed.), La Nouvelle Histoire, Paris, CEPL, 1978, pp. 77-108. 
the soya bean, which grew with particular abundance in the friable soil covering the hills north of Mukden and in the watery meadows of the Liao and Sungari rivers. ${ }^{(5)}$ Climate was also important for transport and hence for the networks of internal and external trade. In summer, the unfrozen rivers can be used to float logs and expedite the movement of agricultural produce from the hinterland, but heavy rains during that season once made movement on the muddy, unmetalled roads impossible. In winter, by contrast, the frozen roads tracks were usable, but the frozen rivers prevented shipping movement. Overall, the vast region of Manchuria-Mongolia with its mountains, forests, and trackless northern wildernesses was for centuries a terrain where population was sparse or nonexistent and where "national" boundaries were vague and largely unenforceable by conventional means.

The social and political systems found in the region adapted to these conditions. Nomadic Mongolians, for example, recognised collective grazing but not individual forms of land ownership, while the Manchurians, enjoying the space of their traditional homeland and organised in localised Banners "north of the wall," formed a political buffer that separated the Han Chinese from the wilder barbarians further to the north.

As a "frontier" region colonised in different ways by different nationalities and ethnic groups, Manchuria was home to a variety of different racial types (Mongols, Manchurians, Chinese, Koreans, Russians, etc.). At many points of contact, these groups had a tendency to mix both by marriage and cultural adoption, and it has been argued that this led them to play a key role in the fluctuating frontiers of settlement and migration. ${ }^{(6)}$

These relatively stable, long-term structures began to show signs of serious disturbance from the middle of the nineteenth century. A fundamental factor here was steam technology. Not only did this open Manchuria to trans-Pacific influences of trade and modern imperialism, but through competing railway systems drew Russians, Japanese, Chinese, and some western nations into conflict in the Manchurian melting pot. The pioneering Russian Chinese Eastern Railway, for example, cut through Northern Manchuria, began to revolutionise the Manchurian economy, and led to the creation of Harbin - a modern Russian-style city. This railway, combined with trading advantages arising from strong positions on the Amur and Ussuri rivers, gave the Russians a dominant role in North Manchuria, the far-reaching political potential of which was demonstrated when Russians briefly occupied Manchuria militarily following the Boxer Rebellion of 1900.
This "railway imperialism" impressed the Japanese, who established the South Manchurian Railway in 1906, immediately following the Russo-Japanese War. Following the Russian model, this enterprise combined railway construction with wider forms of economic development and the acquisition of a variety of extra-territorial and commercial rights. ${ }^{(7)}$ Western activity was also present in the scramble for railway "rights," and the Americans, to whom the Manchurian "frontier" represented a possible Pacific extension of their now closed internal frontier, sought to maintain a Manchurian Open Door. ${ }^{(8)}$ By the end of the century, foreign penetration of Manchuria was also reflected in the presence of seven Treaty Ports and the Kwantung Leased Territory, which was leased first to the Russians and then taken over by Japan. Among the Treaty Ports, Newchwang (Yingkou), was opened to foreign trade and run by the British from 1858. Situated at the mouth of the Liao and ice-free for eight months of the year, the port was used by up to 10,000 small to medium-sized junks that set the foundation for a huge international trade in the soya bean business. On the basis of this economic expansion, Newchwang's status flowered with the emergence of polite society, winter tea dances, and regular reports of its social and business activities in the Shanghai New China Herald. ${ }^{(9)}$

Railway and commercial development was accompanied by western missionary activity. The first Catholic Bishop of Manchuria was appointed as early as 1838 , and in the 1880 s a visiting Protestant in Newchwang attended a Christmas Midnight Mass already so adapted to local custom that the elevation of the Host was accompanied by wild acclamation and a tremendous display of fireworks. Western missionary penetration was hated by the Russians, who supported the expansion of the Orthodox Church in areas under their control. So unpopular was missionary activity with extremist anti-foreign groups that the two main targets of the Boxer rebels in Manchuria were reported to have been the railways and the missionaries. ${ }^{(10)}$

5. China Imperial Maritime Customs, Special Series No. 31, The Soya Bean of Manchuria, Shanghai, 1911.

6. Owen Lattimore, Manchuria: Cradle of Conflict, New York, Macmillan, 1932, especially Chapter 2.

7. The role of the CER is indicated by the company statutes reprinted in Percy Horace Kent Railway Enterprise in China, Edward Arnold, London, 1907, Appendix A IV. The role of the CER model and the SMR is discussed in illuminating detail in a recent study, Yoshihisa Tak Matsukata, The Making of Japanese Manchuria, 1904-1932, Harvard University Asia Center, 2001, Chapters 2 and 3.

8. Michael H. Hunt, Frontier Defense and the Open Door: Manchuria in Chinese-American Relations, 1895-1911, New Haven, Yale University Press, 1973.

9. Bank of Chosen, Economic History of Manchuria, Seoul, 1921, Chapter 1.

10. Adrien Launay, Monseigneur Verrolles et la Mission de Manchourie, Paris, 1895, and "History of Christian Mission," Contemporary Manchuria, Vol. IV No.1, January 1940, pp. 29-55. The description of the Midnight Mass is in H.E.M. James, The Long White Mountain or a Journey in Manchuria, London, Longmans, 1888, p. 394. 
By the 1920s the Manchurian economy was enjoying a boom based on the export of raw materials and the increasing use of modern transport technologies. (II) But while Russo-Japanese rivalry had been temporarily stabilised in favour of Japan, the new force of Chinese nationalism and its search for political form was rising. This political modernisation was manifest not only in measures to reassert tariff and economic authority but also in an expansionist quest to "reclaim" extra-territorial concessions and redefine China's geographical borders, especially in the north and northeast. The rise of Zhang Tsolin, and then of Zhang Xueliang, who allied with the Guomindang (Kuomintang) in 1928, made realisation of these political aspirations seem feasible. The instability of agriculture in North China also encouraged unprecedented northward flows of Chinese migrants, many seeking permanent rather than temporary employment and residence, and this gave demographic substance to China's ambitions for Manchuria. ${ }^{(12)}$

\section{The experience of Manzhouguo}

This, then, is the background against which Yamamuro's explorations of the phenomenon of Manzhouguo after 1932 have to be considered. His study opens by examining the thinking that conditioned Japan's commitment to the Manchurian-Mongolian adventure. He then explores the early stages by which Japan moved from the immediate postMukden (i.e. post-September 1931) situation to the decision to establish Manzhouguo as an "independent" political nation. Finally, he analyses the way in which the early ideals and hopes for Manzhouguo were progressively and cynically betrayed so that the new state became an integral part of the Japanese war machine responsible for horrifying abuses of human rights, coercive exploitation, and ultimate disaster and physical humiliation for Japan and thousands of Japanese in Manchuria.

The starting point for strategic thinking by Ishiwara and the Kwantung Army was reflection on the significance of the First World War. This seemed to the Army leadership to illustrate that the world was entering an era of "protracted" all-out war, based on the mass production and increasing technological sophistication of armaments. Japan needed to ensure that it had both the raw materials for the huge industrial outputs required and the ability to develop the necessary technologies, including revolutionary developments in metallurgy, aircraft construction, vehicles, and wireless. During the war the western powers had leapt ahead of Japan, and in the 1920s made new advances, especially in electri- cal and chemical technologies, with which Japan failed to keep pace. Indeed, in the immediate post-war period, while the western war theatre employed modern tanks, planes, and submarines, the Japanese Army's basic equipment remained infantry rifles of the type used in the Russo-Japanese War of 1905 (Yamamuro p.19).

It was also foreseen that a "protracted" war would within a few decades turn into a "final" war of annihilation in which the protagonists would be the United States versus an East Asia led by a Japan that could draw on the full hinterland of Northeast Asia for resources. Japanese historians provided support for this vision through research indicating that Manchuria and Korea were historically relatively undefined "regions" that could now be logically attached to Japan as a joint entity referred to as Mansen (i.e. ManchuriaKorea). ${ }^{(3)}$ Korea, already a colony of Japan, played an important part in military thinking, given its apparent vulnerability to Russian pressure, and Korean migration into Manchuria also raised questions about the viability of Japanese control in Korea and ultimate responsibility for the Korean population of Manchuria

This military resource argument was reinforced in the early 1930s by the view that the domestic economic crisis in Japan required "outlets" for Japan's surplus population, as well as control of sources of food supply in addition to those already being developed in Korea and Taiwan. "Our national state of affairs," wrote Ishiwara, "has reached an impasse. The critical problems of populations and foodstuffs seem all without solution. The only avenue that public opinion recognizes is boldly to open up Manchuria ..." (Yamamuro, p.17). A further dimension that Yamamuro does not explore is the importance of Manchuria as a market in which Japanese goods could be given a measure of protection against competition from more advanced industrial nations. Manchuria and Korea had already performed this function for Japan's light and textile industries before 1914, but Japan's heavy industries badly needed a similarly advanta-

11. Table 11.1 in Christopher Howe, "Japan's economic experience in China before the establishment of the Peoples Republic of China: A retrospective balance sheet," Ronald Dore and Radha Sinha, Japan and World Depression, Then and Now: Essays in Memory of E.F. Penrose, London, Macmillan, 1987.

12. There were famines in Shantung in 1919,1920, 1926,1927, and 1928. By the late 1920s, over one million Chinese a year were migrating northward. See, "Chinese migrations to Manchuria," Special Study No.3, Report of the Commission of Enquiry, Vol.2. (The "Lytton Commission"), Geneva, 1932. This report with its appendices of expert studies and maps, remains the best account of Manchuria on the eve of the Japanese coup of 1932.

13. Stefan Tanaka, Japan's Orient: Rendering Pasts into History, Berkeley, University of California Press, 1993, pp.246-7. 
Pu Yi, Emperor of the Manzhouguo. hara held the Chair of Colonial Policy in Tokyo from 1923 to 1937 , and his collected works run to 29 volumes. His analysis of colonial Taiwan is so brilliant that it remains in print to this day, and his work on Manchuria, although tempered by the political circumstances in which he found himself, constituted a serious critique of Japanese policies. Yanaihara saw (and foresaw) the significance of economic links between Japan and Manchuria, but at the same time he understood the illusions, fabrications, and hypocrisy surrounding Manzhouguo. He argued that Japan's long-term policy should be to assist the rise and political consolidation of Chinese nationalism rather than to destroy it. ${ }^{(19)}$

Yamamuro describes how, piece by piece, the idealistic visions of Manzhouguo were lost. Manchurian "independence" gave way to political absorption by the Japanese empire. Racial equality was lost as promised shares of appointments and opportunities for Manchurians were ceded to Japanese appointees. And in place of a mutual prosperity came starvation, naked beggars, forced labour, land confiscation, and the horrors of human experimentation. By the 1940s, the nightmares of the chimera were being realised (Yamamuro p.199ff).

\section{Manchurian legacies}

The legacies of the Manzhouguo experiment are numerous. For historians, the first of these is the extraordinary volume and variety of sources to work from. That these are far superior to those for "China proper" is due to the culture and indefatigable efforts of Japanese institutions and individuals. It is these scholarly resources that have made possible the work of Japanese historians and of western specialists such as Ramon Myers, Mark Peattie, Peter Duus, Louise Young, and others. The statistical legacy has been particularly important in enabling scholars to reconstruct Manchurian development and demography in a way that will never be possible for other parts of China.

The historical legacy in post-war Japanese economic management and planning has been mentioned and is well researched, while Louise Young's study has shown us how deeply the Manchurian question influenced Japan's domestic social and political development. The legacy in China is much less well studied, but in the past few years this has begun to change as Chinese concerns have risen concerning the north-eastern provinces, which represented the core of the Chinese development effort throughout the 1950s in spite of the impact of war and Russian industrial theft in Manchuria after 1945. Of the 156 Key Point Soviet projects

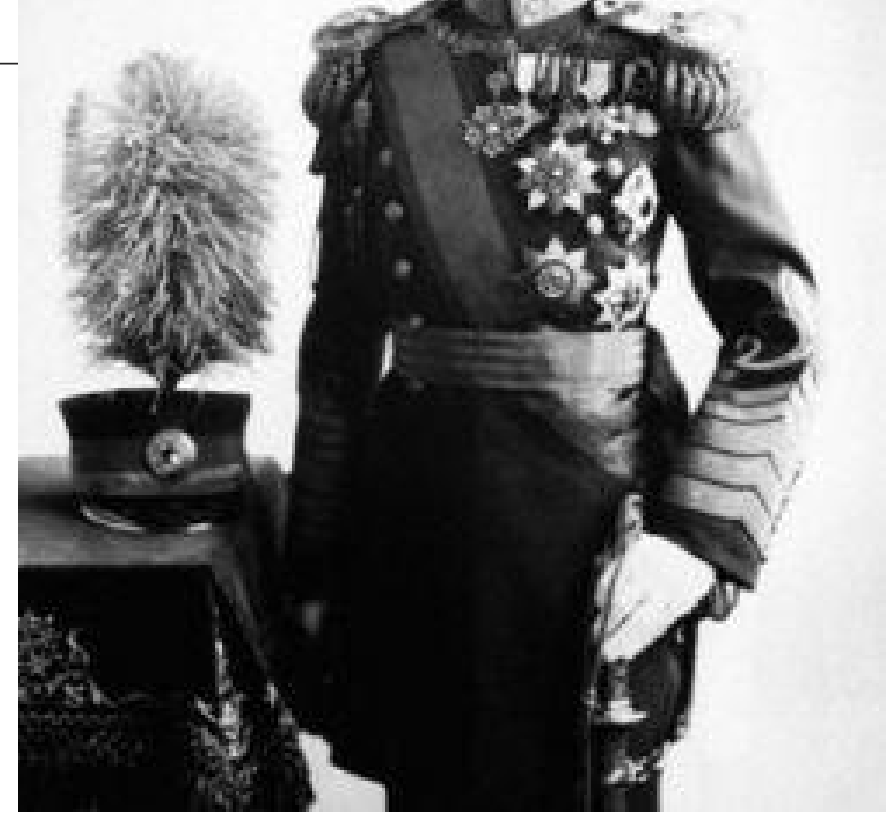

initiated in the First Five Year Plan (1953-57), 54 were in Manchuria, and this boost was reinforced in the 1960s by the development of Daqing, Shengli, and other north-eastern oilfields.

In the early stages of the reform, the rapid development of coastal, export-oriented light industry left the old stateowned industries of the northeast in relative decline. This trend is now being actively reversed, however, and cities such as Qingdao and Dalian are once again becoming the central points for new high technology industrial and service clusters based to a considerable extent on foreign and especially Japanese investment. The peaceful strategy for Japanese trade and investment in China, an experiment in the 1920s ultimately wrecked by the Manzhouguo adventure, is now working. This progress, moreover, is not simply the result of decentralised market relations, but also reflects conscious regional institution building at many levels and on both sides of the Yellow Sea. ${ }^{(20)}$

One issue that remains puzzling to this reader of Yamamuro and the western literature on Manchuria is the failure to pick up on the controversies surrounding the view that Japan needed Manchuria as an "outlet" for surplus population. This view, shared by several western writers including W.R. Crocker and George Bronson Rea, was challenged at the

19. A deeply thought and indispensable account of Yanaihara's life and thought has been provided by Susan C. Townsend in Yanaihara Tadao and Japanese Colonial Policy: Redeeming Empire, London, Curzon, 2000.

20. Three representative studies are: Ning Yi and Dong Ning, Dongbei zazheng:Dongbe wenti baogao (How to put the northeast right: Report of north-eastern problems), World Press, Beijing, 2004; Central Party School, Dongbei dichu deng lao gongye jidi zhenxing zhanliu (Strategies to revive the northeast and similar old industrial regions), Beijing, Central Party School Publishing House, 2004; Shanghai Finance and Economics Research Centre for Regional Economics, Dongbei lao gongye jidi fuxing yanjiu (Research into the revival of the old industrial regions of the northeast), Beijing, Red Flag Publishing House, 2004. 
time by the important demographer Uyeda Teijiro, and by E.F. Penrose, who explored the issue of Japanese Malthusianism in a remarkable book published in 1934. A further exhaustive examination of the issues was provided by Irene Taeuber in her vast work, The Population of Japan . ${ }^{(21)}$

The problem at the time was that the statistical techniques and demographic models needed to measure and predict fertility change and the long-term trajectory of the Japanese population were in their infancy. Penrose, however, who read Japanese fluently, was at the forefront of this work, integrating it with his own pioneering measurement of Japan's agricultural and industrial output, and with the latest thinking (by the Swedish economist Bertil Ohlin) on the theory of comparative advantage in international trade. In essence, Ohlin pointed out that the exchange of goods could substitute for the "necessity" of factor, e.g. population movement. Penrose and Uyueda both pointed out that correctly understood, Japanese fertility was already declining in the 1920s, and Penrose drew on his economic analysis to argue that what Japan needed was a more liberal trading environment, not more land, an argument that Tobata Seiichi (the most revered of Japan's twentieth century economists) revived in the immediate post war period.

\section{War and the problems of reconciliation}

Yamamuro emphasises that for the survivors, "the wounds of Manzhouguo continue to ache and will not heal or disappear" (Yamamuro, p. 20). Clearly, too, these wounds do not seem to die with the original sufferers, but live on in political consciousness. One asks, therefore, what possible developments may ease this problem. The parallel with Western Europe is perhaps of some help in considering this question.

The combatants on the western front in World War Two all have their own places of memorial and ceremonies of remembrance, but the joint remembrance of the June $6^{\text {th }}$ invasion of Normandy has grown in significance in recent years. The $50^{\text {th }}$ and more recently the $60^{\text {th }}$ anniversary (2004) were particularly big occasions.

On the weekend of 6 June 2004, more than 20 world and government leaders gathered in the village of Arromanches on the Normandy coast. A small fishing village with a history going back to Roman times, Arromanches became a popular resort for Parisians with the arrival of the railway in the nineteenth century. The destiny of this village was changed forever when it was chosen by military planners to be the geographical centre point of the D-Day invasion and the site of the war's only successful artificial harbour.

The world leaders who met at Arromanches included not only the leaders of all the Allied and Commonwealth countries together with President Putin of Russia, but also Chancellor Schroeder of Germany. The inclusion of a German leader for the first time obviously reflected a very high-level political decision. More important, however, was the fact that the ceremony was also a product of grass roots reconciliation, particularly involving the local population. Normandy suffered thousand of casualties from Allied bombing during the course of the campaign of 1944, not to mention the destruction of several of beautiful medieval cities. Few Normans escaped the impact of these tragedies, and without willing local participation the event would not have worked. Underlying this grass roots acceptance of reconciliation was an important psychological reality. As people age, it seems that not only does long-term memory sharpen, but the need for reconciliation with enemies - especially among war combatants - seems to become more pressing. The minimum age for veterans at the $60^{\text {th }}$ anniversary would have been about 80 years old, making this ceremony the last that many could hope to attend. There is reason to think that similar factors might be at work in Sino-Japanese relations, as evidenced by the experiences of individuals who have participated in the remarkable Japanese-British reconciliation meetings in recent years. The roadblock to Sino-Japanese reconciliation, therefore, may lie not with those who have first-hand experience, but with those in the grip of simplistic, sometimes mistaken histories. That is why the endeavours of scholars such Yamamuro and those beginning to work in the joint Sino-Japanese historical forums are so important.

Interestingly, the Chinese observed what happened at Arromanches with close attention, sending a team from Central Television to record the event and talk to the oldest veterans they could find. In discussion, the young team agreed that a reconciliation of the kind they had observed was not feasible in the Far East for the present, but they hoped nonetheless that ultimately it would become so. $\bullet$

21. E.F. Penrose, Population Theories and their Application, With Special Reference to Japan Food Research Institute, Stanford, 1934. Irene B. Taeuber, The Population of Japan, Princeton University Press, 1958. The writings of Yueda are listed in Taeuber's bibliography. 